\title{
THE TETANOID TRAINING METHOD IN HIGH-PERFORMANCE ALPINE SKIING
}

\author{
Iancu RĂCHITĂ ${ }^{1 *}$, Nicoleta LEONTE ${ }^{1}$, Ofelia POPESCU ${ }^{1}$, Marian PETROF ${ }^{1}$ \\ 1 "Politehnica" University, Department of Physical Education and Sport - Kinetotherapy, Bucharest, Romania \\ *Corresponding author: rachitaiancu@yahoo.com
}

DOI: 10.35189/iphm.icpesk.2019.35

\begin{abstract}
Alpine skiing, due to the new configuration and shape of the skis, the elevators, as well as the preparation of the slopes for competitions, is becoming more and more a sport of strength, which brings about changes in the requirements for the physical training. Alpine skiing requires special forms of strength, such as explosive strength and endurance strength, which involve loads and complex training methods. Thus, increasing the efficiency of the physical training becomes mandatory for coaches and athletes. The aim of the research is to identify efficient methods and means to optimise non-specific (landbased) training in alpine skiing to achieve the best performance. The tetanoid training method is used during the hypertrophic and the maximum strength phases of the training. The research was conducted over six months and included personalised training programmes, the tetanoid method, as well as participation in international competitions (European Youth Olympic Festival - EYOF). The research subjects are members of the Junior National Alpine Ski Team. They were assessed and measured using the OptoJump analysis and measurement system by applying the Counter Movement Jump test. The results obtained in the final test revealed the effectiveness of the programmes included in the training of athletes, in the sense that their explosive leg strength has increased. On the other hand, the results obtained in competitions have confirmed the need to improve the technical and tactical training.
\end{abstract}

Keywords: tetanoid training, non-specific training, OptoJump, alpine skiing.

\section{Introduction}

Alpine skiing has become more and more a sport of strength, which has the effect of changing the requirements for the physical training of athletes.

Alpine skiing requires special forms of strength, such as explosive strength and endurance strength, which involve complex training loads and need special attention. Due to the development of the equipment, alpine skiing has become more dynamic. This increases the centrifugal force on the skier and the inclination of the skis' edges. (Patterson, Raschner, \& Platzer, 2009)

Explosive strength is the ability of the neuromuscular system to develop as quickly as possible an amount of strength capable of defeating a resistance based on rapid voluntary muscular contraction. The maximum exploitation of an athlete's potential is possible only when the training is systematically planned in the long-term (Neagu, 2015, p. 47). In alpine skiing, it is necessary to produce as much strength as possible in the shortest possible time so as to take the optimal trajectories as tight as possible and with lower rays. Explosive strength plays an essential role in using the skis with maximum efficiency. The maximum strength generation is improved as a result generating muscular tension and a larger number of motor units. (Grigoroiu, Pelin, Netolitzchi, \& Wesselly, 2016)

Similar research in the field shows that jumps are accepted methods for testing strength in skiing (Bosco, 1997; Mueller, \& Schwameder, 2003).

The tetanoid training method is used in the nonspecific training, which aims at developing maximal muscle tension. In the opinion of Bompa and Carrera (2006, pp. 168-169), this training method involves a low contraction rate, dispersed by isometric contractions.

Alpine skiing is characterised by a high degree of complexity, technicality, dynamism and spectacularity, which are materialised by the content and dynamics of the competition events.

\section{Problem statement}

Physical training in alpine skiing cannot be dissociated from and planned independently of the snow training, this being complemented, ensured and planned by the land-based (non-specific) training (Harald, 1995, p. 4).

The tetanoid training method in alpine skiing is used during the phases of hypertrophy and maximum strength training. The goal is to develop the maximum muscle tension, the training being done with loads between 70 $100 \%$ (Bompa \& Carrera, 2006, p. 168). 
In order to induce a tetanoid state for the benefit of the performance, the following methods are to be observed: the isometric, isometric-dynamic, dynamic-explosive contraction, the complete exercise, followed by 3-5 plyometric exercises.

For the analysis and comparison of the data obtained in the training, we used the OptoJump system, by means of which we applied the Counter Movement Jump (CMJ) test. This system gave us the possibility to consult and compare the data in different tests. This measurement system has been used in various studies (Graur \& Făgăraș, 2013; Bosquet, Berryman, \& Dupuy, 2009) that attest the validation of the results obtained and allow its use in the evaluation and research of jumps under specific conditions (Becea, Pelin, Braneț, \& Răchită, 2017),

Through this study, we intend to open new directions for the guidance and improvement of the physical training for high-performance alpine skiers.

\section{Research question}

If the level of physical training in alpine skiers is known, are coaches helped to achieve better sports performance?

\section{Purpose of the study}

Applying the tetanoid training technique we aim at: creating new models, improving the athletes' results and optimizing sports performance in high-performance alpine ski.

The applicative value of the paper consists in the design of an experimental model that includes the application of the tetanoid training method to skiers in the national team.

\section{Material and Methods}

\section{Research subjects and location}

In order to carry out the experiment, two subjects (C.M. and R.D.) from the National Alpine Ski Team were selected for the research. They were verbally informed about the test specifics and agreed with the experiment. The research was conducted over six months (July-December 2018), during which tetanoid training programmes were used. Between 9 and 15 February 2019, the athletes participated in the European Youth Olympic Festival (EYOF).

The research was carried out as follows:

- 7 July 2018: the initial test was performed by applying the CMJ test;

- 8 July to 18 December 2018: the training programmes were applied;

- 18 December 2018: the final test was applied in Poiana Brașov (Romania).

The participation in the Olympics took place between 9 and 15 February 2019.

\section{Research techniques}

The following research methods were used: experimental method, scientific documentation by which we laid the theoretical foundation of the paper, graphical method, the test and measurement methods.

In order to carry out the research (the case study), the athletes were measured and assessed using the OptoJump through the CMJ test. In our research, the OptoJump system was used to assess the explosive strength. The data are presented in tabular and graphical forms.

\section{Results}

By applying the CMJ test, the level of explosive strength was determined. In the initial and final tests, the maximum and minimum values of the jumps were tracked. The height of the jump, the arithmetic mean and the difference between the maximum and the minimum jump were calculated.

In the initial test, athlete R.D. managed a $26.6-\mathrm{cm}$ jump. In the final test, the jump height was 35.9. The difference in height between the two jumps is $9.3 \mathrm{~cm}$. The arithmetic mean between the two jumps is 31.25 . (Figure 1) 


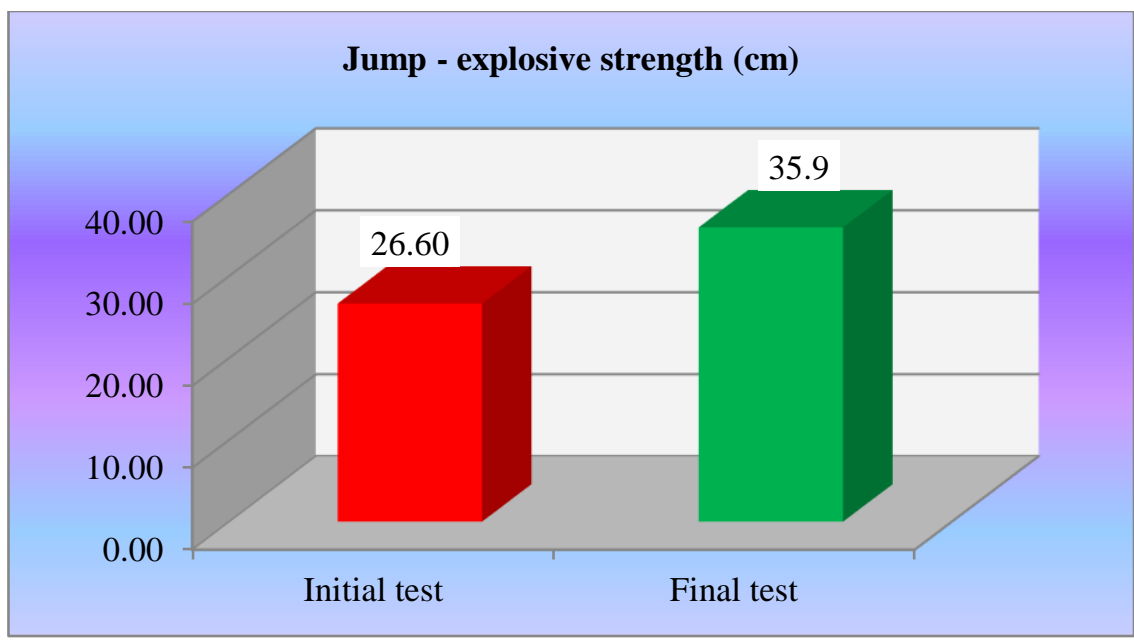

Figure 1. Results for athlete R.D. in the initial and final tests

In the initial test, athlete M.D. managed a 32-cm jump, and in the final test, the jump height was 39.4 (Figure 2). The difference between the two jumps is $7.4 \mathrm{~cm}$. The arithmetic mean between the two jumps is 35.7 .

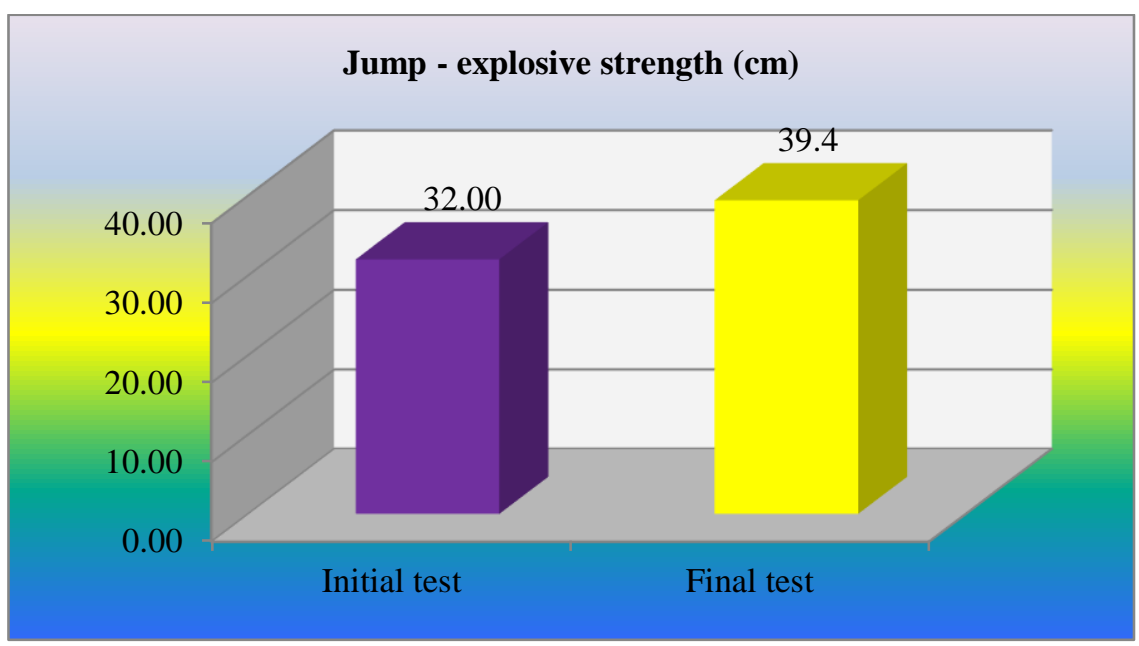

Figure 2. Results for athlete M.D. in the initial and final tests

Between the two tests, we applied the tetanoid method to improve the explosive strength of athletes. Their training focused on the development of explosive strength, maximal strength and muscle hypertrophy. The snow training aimed to develop the specific exercise capacity, as well as the technical component in the special slalom (SL) and giant slalom (GS) events.

The results obtained in competition by the two athletes are presented in Table 1 (they participated in the SL and GS events at the EYOF 2019).

Table 1. Results obtained in the competition

\begin{tabular}{lccc}
\hline \multicolumn{1}{c}{ Athlete } & Event & Result & Cumulated time \\
\hline C.M. & SL & 37 & 6.26 \\
C.M. & GS & 38 & 7.16 \\
R.D. & SL & 42 & 8.09 \\
R.D. & GS & 44 & 9.26 \\
\hline
\end{tabular}


As seen in Table 1, athlete C.M. won the 37th place in SL and the 38th place in GS, out of 104 participants. Athlete R.D. was ranked 42nd in SL and 44th in GS, out of 104 participants. For athlete C.M., the cumulated time difference in the two innings between the 1st ranked and him was $6.26 \mathrm{sec}$ in SL and $7.16 \mathrm{sec}$ in GS. For athlete R.D., the difference between the two innings was $8.09 \mathrm{sec}$ in SL and $9.26 \mathrm{sec}$ in GS. Comparing the results obtained by the two athletes, we can see that athlete C.M. scored better in this competition. Referring to the physical tests, the difference between athlete C.M. and athlete R.D. is $4 \mathrm{~cm}$ for the maximum jump in the final test.

\section{Conclusion}

The proposed training programmes have proven to be viable and effective, which is supported by the data obtained in the tests, and the results achieved in competitions emphasise their improvement compared to previous editions, but the technical component still needs to be improved.

The test results have clearly and concretely highlighted the role of physical education and training programmes in achieving performance in alpine skiing.

The level of performance in alpine skiing is determined not only by the training programmes, but also by a combination of factors that intervene in the athlete training, namely: staff, physiotherapists, optimal training conditions, snow quality, service man and participation in as many international skiing competitions as possible.

We believe that we cannot generalise the conclusions drawn, but in terms of the results obtained, we can open new directions of research and guidance for the physical training.

In conclusion, very good physical training conditions the performance of the athlete in competitions by sustaining the effort at maximum parameters.

\section{Authors' Contributions}

All authors contributed equally to this study and should be considered as main authors.

\section{References}

Becea, L., Pelin, R. A., Braneț, C., \& Răchită, I. (2017). A comparative study on the indirect assessment of leg extensor power using simultaneously the jump-and-reach test from Alpha-Fit and the Optojump system. In I. Roceanu (Ed.), Proceedings of the $13^{\text {th }}$ International Scientific Conference "eLearning and Software for Education" (Vol. 3, pp. 154-160). Bucharest: Editura Universității Naționale de Apărare "Carol I". DOI: $10.12753 / 2066-026 \mathrm{X}-17-196$

Bompa, T. O., \& Carrera, M. C. (2006). Periodizarea antrenamentului sportiv - Planuri științifice pentru forță și condiția fizică pentru 20 discipline sportive [Sports training periodisation - Scientific plans for strength and physical condition for 20 sports disciplines]. București: Tana.

Bosco, C. (1997). Evaluation and planning of conditioning training for alpine skiers. In E. Müller, H. Schwameder, E. Kornexl, \& C. Raschner (Eds.), Science and skiing (pp. 150-158). London: E \& FN SPON.

Bosquet, L., Berryman, N., \& Dupuy, O. (2009). A comparison of 2 optical timing systems designed to measure flight time and contact time during jumping and hopping. Journal of Strength and Conditioning Research, 23(9), 2660-2665. https://doi.org/10.1519/JSC.0b013e3181b1f4ff

Graur, C., \& Făgăraș, S. P. (2013). Differences in the explosive force of the lower limbs between female volleyball teams. Palestrica of the Third Millennium - Civilization and Sport, 14(4), 288-291. Retrieved from http://webcache.googleusercontent.com/search?q=cache:-DF6Nc2G5ysJ:pm3.ro/pdf/54/10\%2520-

$\% 2520$ graur\% $2520 \% 2520288-291 . \mathrm{pdf}+\& \mathrm{~cd}=1 \& \mathrm{hl}=\mathrm{ro} \& \mathrm{ct}=\mathrm{clnk} \& \mathrm{gl}=\mathrm{ro}$

Grigoroiu, C., Pelin, R. A., Netolitzchi, M., \& Wesselly, T. (2016). The development of the maximum force by means of the "Maxex" method for tennis players aged between 16 and 18. In I. Roceanu (Ed.), Proceedings of the $12^{\text {th }}$ International Scientific Conference "eLearning and Software for Education" (Vol. 3, pp. 355-360). Bucharest: Editura Universității Naționale de Apărare "Carol I". DOI: 10.12753/2066-026X-16-230

Mueller, E., \& Schwameder, H. (2003). Biomechanical aspects of new techniques in alpine skiing and skijumping. Journal of Sports Science, 21(9), 679-692. https://doi.org/10.1080/0264041031000140284

Neagu, N. (2015). Manual tehnic cu privire la optimizarea pregătirii fizice specifice înotătorilor, pentru studenții din Universitatea Politehnica din București [Technical manual on the optimisation of physical 
International Proceedings of Human Motricity/ ICPESK 2019

Supplementary Issue of Discobolul - Physical Education, Sport and Kinetotherapy Journal, 2019

training specific to swimmers, for students at the "Politehnica" University of Bucharest]. București: Electronica 2000.

Patterson, C., Raschner, C., \& Platzer, H. P. (2009). Power variables and bilateral force differences during unloaded and loaded squat jumps in high performance alpine ski racers. Journal of Strength \& Conditioning Research, 23(3), 779-787. https://doi.org/10.1519/JSC.0b013e3181a2d7b3 